\title{
P̈̈̈̈KIRJOITUS
}

\section{AKATEEMINEN YRITTÄJYYS JA YLIOPISTOJEN MURROS}

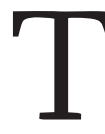

ALOUTEEN JA TYÖELÄMÄÄN perustuvat tavoitteet ovat suomalaisissa yliopistoissa yhä määrävämpiä. Yrittäjyys ja yrittäjämäisyys on yliopistojen toimintaa ja akateemista työtä ohjaava uusi toimintatapa. Suorituskeskeisyys, välineellisyys ja yritysmaailman mallit ovat tehneet yliopistoista keskenään kilpailevia tuotantolaitoksia, jotka suoltavat markkinoille "tuotteita" tutkintoina ja julkaisuina yltääkseen rankinglistojen huippujen joukkoon.

Korkeakoulujen ja yliopistojen odotetaan verkostoituvan elinkeinoelämän kanssa ja vastaavan joustavasti elinkeinoelämän tarpeisiin kansallisen kilpailukyvyn takaamiseksi. Tutkija-opettajien tulee julkaista yhä enemmän, opettaa yhä paremmin, hankkia rahoitusta, kansainvälistyä ja kaupallistaa tutkimustuloksensa. Opiskelijoiden tulee opiskella vielä tehokkaammin ja nopeammin, harjoitella yrittäjyyttä ja kehittää yrittäjämäisiä taitoja.

Yrittäjyys on moniulotteinen, määritelmiä pakeneva ilmiö, joka muuntuu kameleontin tavoin ja saa aina uusia sävyjä. 'Akateemisella yrittäjyydellä’ voidaan viitata korkeakoulujen toimintaan ja johtamiseen yleensä, tutkimustiedon kaupallistamiseen tai yrittäjyyskasvatukseen ja -koulutukseen, jonka tavoite on oman yrityksen perustaminen tai yrittäjämäisenä palkkatyöläisenä toimiminen. Bisnesyhteydestä irrotettuna 'yrittäjyys' ja 'yrittäjämäisyys' viittaavat usein samaan ilmiöön kuin työllistettävyys (Laalo, Kinnari \& Silvennoinen 2019): yksilön taitoihin, persoonallisiin kykyihin ja työllistymisominaisuuksiin, kuten aktiivisuuteen, joustavuuteen ja itseohjautuvuuteen.

Uusliberalistinen politiikka ja yrittäjyyskasvatus sen lomassa rantautuivat Suomeen ja koulutusjärjestelmäämme 1990-luvulla. 2010-luvulta alkaen Suomessa koettiin ennennäkemätön yrittäjyys- ja start-up-buumi. Se lähti liikkeelle vasta perustetusta Aalto-yliopistosta vuonna 2010, kun ensimmäinen opiskelijoiden yrittäjyysyhdistys (Entrepreneurship Society), tutummin ES, perustettiin. Nyt vastaavia yhdistyksiä on parikymmentä ympäri maata.

YRITTÄJYYSBUUMISSA SUOMESSA rekisteröitiin satoja start-up-yrityksiä. Kehitystä on kutsuttu 'vallankumoukseksi', eihän Suomi ole koskaan ollut yrityshautomoiden luvattu maa. (Lehdonvirta 2013.) Aalto-yliopiston lisäksi muut suomalaiset yliopistot ovat sisällyttäneet yrittäjyyden strategioihinsa ja opetustarjontaansa. Turun yliopisto määrittelee itsensä yrittäjyysyliopistoksi, jonka tavoite on "tukea yrittäjämäistä asennetta ja yrittäjyyttä tukevia toimintatapoja koko yhteisössä” (www.yrittajyysyliopisto.fi). 
Vuonna 2010 voimaan tullut yliopistolaki vahvisti yrittäjyyttä ja yrittäjämäistä toimintatapaa. Yliopistot ovat taloudellisesti aiempaa itsenäisempiä, ja niillä on tulosvastuuta. Vuodesta 2011 lähtien yliopistoihin kohdistuneessa kulukurissa valtion perusrahoitus on vähentynyt: vuonna 2016 täydentävän rahoituksen osuus oli jo lähes puolet kokonaisrahoituksesta. Yliopistojen julkinen rahoitus perustuu kokonaisuudessaan kilpailuun, kun valtion perusrahoituskin riippuu indikaattoreista, kuten tutkintojen ja julkaisujen määrästä.

Tutkimusinvestoinnit ovat vähentyneet kansainvälisestikin verraten rajusti: vuonna 2010 niiden osuus oli 4 prosenttia, vuonna 2016 enää 2,7 prosenttia. Henkilökuntaa on karsittu, ja opetusresurssit ovat pienentyneet. Samalla Suomi on menettänyt asemansa korkeimmin koulutettuna maana Euroopassa ja taloudellisen yhteistyön ja kehityksen järjestön (OECD) jäsenmaissa.

MITEN KÄY POHJOISMAISELLE tasa-arvon eetokselle, akateemiselle tiedolle, kriittiselle ja riippumattomalle tutkimukselle ja opetukselle? Leikkaukset, kehittämispaineet sekä laaduntarkkailuun, markkinoihin ja valvontaan perustuvat käytännöt ovat muokanneet tieteen ja korkeakoulutuksen asemaa ja autonomiaa sekä akateemista työtä perustavalla tavalla. Tilat ja mahdollisuudet opettaa ja tutkia yliopistossa, jossa opetusta ja tietoa arvostetaan taloudellisena investointina, ovat merkittävästi kaventuneet.

Työllistettävyyden ja yrittäjyyden painotukset uhkaavat syrjäyttää teoreettisen tiedon ja kriittisen ajattelun, työelämässä kun opiskelijoiden mukaan arvostetaan pikemminkin yrittäjämäisiä kuin akateemisia taitoja (Räty ym. tulossa). Teoreettisuus ja kriittisyys ovat aikaa vieviä, käytännön osaamista arvostavan työelämän kannalta tarpeettomia taitoja, joista yliopistoissa tulisi päästä eroon.

Aikuiskasvatuksen akateemisen yrittäjyyden teemanumeroa koostettaessa Suomeen muodostettiin pääministeri Antti Rinteen (sd.) johdolla uusi hallitus, joka lupaa panostaa yliopistojen perusrahoitukseen, käytännössä tutkimukseen ja opetukseen. Hallitusohjelman kirjaus on tärkeä myönteinen signaali.

Keskustelua täytyy kuitenkin jatkaa siitä, miten taata laadukas, kriittinen ja riippumaton tutkimustieto tulevaisuudessa. Millaisia akateemisia kansalaisia ja tulevaisuuden toimijoita koulutamme? Mikä on yliopiston tarkoitus ja tehtävä 2010-luvun Suomessa?

Päivi Siivonen

\section{Lähteet:}

Laalo, H., Kinnari, H. \& Silvennoinen, H. (2019). Setting New Standards for Homo Academicus: Entrepreneurial University Graduates on the EU Agenda, European Education, DOI: 10.1080/10564934.2018.1489729.

Lehdonvirta, V. (2013). Helsinki Spring: An essay on entrepreneurship and cultural change. Research on Finnish Society 6, 25-28.

Räty, H., Kozlinska, I., Kasanen, K., Siivonen, P, Komulainen, K. \& Hytti, U. (tulossa). Being stable and getting along with others: Perceived ability expectations and employability among Finnish university students. Social Psychology of Education. 